\title{
Abortion Wishes and Abortion Prevention - Women Seeking Legal Termination of Pregnancy During the 1950s and 1960s in Finland
}

\author{
MIINA KESKI-PETÄJÄ, M.Soc.Sc., Senior Statistician \\ Statistics Finland and The Population Research Institute, Väestöliitto, \\ Helsinki, Finland
}

\begin{abstract}
This article studies Finnish abortion-seeking women in the 1950s and 1960s by investigating the life situations of the abortion-seeking women and their possibilities to regulate childbearing under the 1950 Abortion Act. During the 1950s and 1960s, abortion was legal in Finland only on medical, ethical or eugenic grounds. The data consists of patient documents of the Finnish Family Federation's (Väestöliitto) Tampere social counseling service (sosiaalineuvola) from the years 1955 and 1968 and the documents mainly comprise abortion requests. Results show that in 195583 percent and in 196868 percent of the abortion-seeking women were married. 90 percent of them had two or more children and the mothers often requested abortion because of poor financial or social circumstances. The family conditions of these women were often described as difficult, as they had the main responsibility for taking care of and providing for their families. The majority of the abortion requests were denied. In 1955, only 16 percent of the abortion-seeking women received an affirmative decision from the Family Federation whereas the share of admitted abortions in 1968 was 42 percent. The documents show a severe collision between the women's wishes for abortion and the society's interest to prevent abortions for pronatalist reasons. The data also indicates that women were not treated equally because their own determined and persistant behaviour as well as the doctoral practices influenced the abortion decisions.
\end{abstract}

Keywords: abortion, pregnancy, maternity policies, social counseling service, population politics, pronatalism, individualization, demographic transition

\section{Introduction}

The first legislation liberalizing abortion in Finland came into effect on July $1^{\text {st }}, 1950$. The Act allowed abortion on certain strict grounds. Termination of pregnancy was to be performed only with the consent of two doctors if the woman was stated to have medical, ethical or eugenic grounds for the procedure. The 1950 Abortion Act was not abated until the creation of the 1970 Abortion Act, which allowed abortions to be 
performed on social grounds alone. The aim of the 1950 Abortion Act was to eliminate illegal abortions and to keep the abortion rates at minimum. The Act called for an abortion prevention strategy where the objective was to help unwillingly pregnant women to see the joys of childbearing in their time of distress. Thus, abortion wishes were to be controlled with personal support and guidance given by professionals of maternity care and of medicine. Under the supervision of the National Board of Health, the responsibility of abortion prevention work was given to the Finnish Family Federation (Väestöliitto) and its social counseling services (sosiaalineuvola).

Whereas researchers in Finland have studied social motherhood (Nätkin 1994 and 1997; Satka 1994; Anttonen 1994) as well as maternity and pronatalist policies (Helén 1997), only few studies (Sumu 1970; Tuomaala 2011) have focused on the individual's viewpoint on the abortion decisions under the 1950 Abortion Act. The social history of abortion and women's abortion intentions have, to some extent, been studied abroad (Lennerhed 2008; Fisher 1999; Reagan 1997), but the Finnish research on history of abortion has focused mainly on legislation and public debate associated thereto (Meskus 2001 and 2003; Ala-Nikkola 1997; Ervasti 1994). Thus, using the patient data of the Family Federation's Tampere social counseling service, this study aims to portray the women's perspective of abortion seeking and the way the 1950 Abortion Act was interpreted and applied in practice.

Firstly, the aim of the study is to investigate the life situations of the abortion-seeking women and their possibilities to make decisions about their own childbearing. These findings were subsequently compared to the image portrayed in public of the women as objects of abortion prevention. Secondly, the study aims to examine the possible changes that occurred in the abortion decisions as well as the changes in abortionseeking women and their life situations under the 1950 Abortion Act by comparing the data of 1955 to that of 1968.

\section{Materials and methods}

The patient data of Tampere's social counseling service is comprised of 7000 patient documents from the years 1953-1972. In this study, 214 documents from 1955 and 396 documents from 1968 were analyzed. Each patient document consisted of a structured question form and a free-form text covering the women's situation in more detail. Both sections were recorded by the social nurse. Some documents also included medical certificates, official statements and correspondence. The documents from the year 1955 show established practices of abortion prevention five years after the 1950 Abortion Act came into force. By contrast, the year 1968 represents practices under the same Act but in a changed attitudinal climate and therefore shows changes in the application of the Law. The aforesaid data have been supplemented with some contemporary studies, nationwide statistics and the Committee reports preceding the Abortion Acts of 1950 and 1970. 
The method of the study consists of qualitative content analysis and descriptive quantitative analysis. The former utilizes elements of both theory-based and data-based content analyses (Tuomi and Sarajärvi 2009). This enables the study to focus on the women's perspective and their reasons for abortion seeking as it was presented in the documents. All the patient documents were first classified by reason of visit, motives for seeking abortion and marital status. The abovementioned groups were thereafter analyzed by key variables (age, occupation, education, previous births, contraception) in order to form key figures and dependencies. In addition, a smaller sample was investigated more closely by reorganizing, classifying and interpreting the data. The free-form sections containing detailed descriptions of the women's situation in life became the core of this qualitative analysis. In particular, women's motives and their social and financial situations were explored.

Due to the delicacy of the data and the confidentiality obligation bounding the researcher, no identifiable information was recorded from the original documents. All names, dates of birth, places of birth or resident and identifiable information concerning family and relatives were either removed or coded before the analysis.

The practices of the counseling service posed the first methodological challenge when processing the data. It was at times difficult to investigate the grounds for seeking and admitting abortion. For instance, the abortion requests were written by the social nurse, who categorized the requests as either health related, financial or social reasons. The free-form section was written in such detail that one could not always differentiate the aspects women themselves emphasized in their requests. In some cases, also the grounds for admitting abortion or the decisions were not clearly documented. The varying recording practices influenced the viewpoint of the study, as not all the decisions and their grounds could be statistically analyzed.

Investigating one counseling service in a certain limited area naturally raises the question of validity. How do the women of this study represent Finnish women that intended to go through with abortion under the 1950 Abortion Act? To overcome this challenge, the data was reviewed against the nationwide abortion statistics and the few written stories of women with unintended pregnancies at the time (see Sumu 1970; Lennerhed 2008; Tuomaala 2011). Some national statistics were only available from 1958 onwards. The patient documents demonstrate the situations of women from certain area and social class - strong generalizations are not to be drawn from this first study of these documents. The primary goal is to present the experiences and alternatives of the women visiting this particular social counseling service. One can only assume that their experiences were familiar to many women nationwide.

Thirdly, the reliability of the data needs to be considered. The social nurse became seemingly the most important contact to the women visiting the counseling service. One could also see her care and support as a way of slowly adjusting women to their 
motherhood since the nurse was an expert of prenatal care and trained to diminish abortion intentions. Helén $(1997,209,244-247)$ sees the counseling as a form of control and calls the nurse a "gatekeeper" with power to decide what sort of help the women needed. The nurse evidently led the discussion, since the files show that same topics were covered with all the women and the descriptions and choices of words are very much alike. On the other hand, certain topics, such as contraception, were not to be discussed with all patients (Auvinen 1991, 223; Ritamies 2006, 171). If these discussions took place, they were not documented. Thus, one must take into account that neither the visits nor the women's stories come across fully authentic from the data.

It is evident that the women may have exaggerated their need to abort. Still, there is no indication of the stories being fictitious, for instance in relation to their living arrangements or the behavior of their husband. If need be, the counseling service evaluated the truthfulness of the stories. The women were guided to medical examination and their family and living conditions were, at times, verified from the parish or the municipality. For instance, in the post-war Finland the use of alcohol was monitored to the extent (Kahlos 2006, 188) that the unwanted alcohol abuse of the women's spouses, which was often discussed at the counseling service, could already have been in the record of the officials. Overall, the data are judged as reliable indicator of the women's life situation. The encounters of the women and the nurse provide the best cues documented on the logic of abortion seeking. The nurse's subjective accounts and the women's exaggerated behavior reflect the attitudes and practices of the time.

\section{Context of the study: Changing motherhood, fertility behavior and modern life}

The theoretical framework consists of the individualization of modern life, the concepts of the mother citizen and maternalism and of bio-political action vis-à-vis women (see Helén 1997). The focus of the study is on the relation between individual women and institutions.

Modernity can be understood as a project of individualization fostered by expert power and other institutions (Jallinoja 1991; Bauman 1996). In the 1930s, fertility started falling as the Finnish population gradually shifted towards a two-child family. Partly as a reaction to this, many governments and NGOs including the Finnish Family Federation promoted pronatalist measures. Legislation on sexual activities aimed at protecting the collective entities such as communities, societies and families during the post-World War II period in Europe (Frank, Camp and Boutcher 2010). However, the gradual advent of sexual and moral liberalization challenged traditional views and promoted the free will of the individual over sexual and reproductive decisions (Herzog 2011, 2-5, 133). 
An estimate of 25 000-30000 illegal abortions were performed annually in Finland before the 1950 Abortion Act (Ervasti 1994, 85-86). As criminal legislation failed to eliminate the problem of illegal abortions, the matter was trusted to the power of medical experts. In this period, mothers and women were subjected to the pronatalist needs of the society (Helén 1997; Meskus 2003). Helén (1997, 48, 53) states that families were seen as population production units and women as mere maternal bodies whose main task in life was to give birth to healthy citizens. This biopolitical discourse was enabled by the importance and the position of experts. Medicalization, the broadening concept and influence of medicine in the society, led to the trimming of human behavior and unlikeness to fit medical definitions (Tuomainen, Myllykangas, Elo and Ryynänen 1999, 15; Zola 1972). The moral point of view of the abortion question was disregarded and abortions were seen as a medical and pronatalistic matter. For instance, women's wish to abort was diagnosed as "gravidity depression" by the doctors. The example illustrates how a medical explanation was provided to explain why some women did not recognize their "natural" will to childbearing (Saloheimo 1950).

Sociologists studying Finnish post-war motherhood have emphasized women's own agency in creating a "mother citizen" (Nätkin 1994 and 1997; Satka 1994). The women organizations encouraged women into "voluntary social motherhood" (Satka 1994, 85,91 ) and women themselves took pride in being hard working and resilient mothers who cared not only for their families but for the whole nation (Nätkin 1994, 150-153). "Social motherhood" ensured women a way to move from the private to the public sphere (Anttonen 1994, 220). Social motherhood is associated with the familistic family model where moral order and family values are put before any individual aspirations. In post-war Finland, families were seen to be in need of societal support and therefore the familistic model was strengthened by pronatalist family and social policies. It was not until the 1960s that these familistic social policies were to be questioned.

Maternalism, whether understood as a political movement or way of speaking or acting, has also been proposed as a concept describing the thoughts and choices common to all women of the period, including those who were single (Nätkin 1997, 209-210). In this study, the concepts of maternalism and social motherhood are used as starting points to study abortion-seeking women in a society that presumed them to naturally want many children.

The 1950 Abortion Act and its practices date to the spread of modernity in Finland. The legislative work commenced, as society demanded the help of its citizens to ensure righteous moral values as well as population growth. These aims collided strongly with individual needs. The wish to abort appeared acceptable only among women who already had performed their citizen duty as mothers. The law was passed during a time that qualified as what Jallinoja (1991) calls "rational modern" but was thereafter in effect for twenty years, well into and beyond the times of changing attitudes on 
sexuality and childbearing. The more liberal Abortion Act that came to allow abortion also on social grounds came into effect in 1970.

Lena Lennerhed (2008) brings out simplifications made in the Swedish public debate over women's role. Lennerhed describes the "modern woman" as a woman quite similar to the Finnish mother citizen. This woman's goal was to be a mother. She was therefore seen as a normal and a real woman compared to the rational and liberal "new woman". This woman was a student or had a job. She chose whether she wanted to be a mother. The new woman is often associated with the idea of abortion rights. (Ibid., 11.) The ideas of both the modern woman and the new woman can be seen in the Finnish abortion committee report. However rational and decisive the new woman was seen, the committee was not willing to acknowledge her full power of decision over her own body. Women didn't have the right to decide for the fetus either since it was seen as a being of its own (Com. 147-149). This was the only time the fetus's human worth was mentioned in the report. As moral and religious arguments of this kind have been quite common abroad, they were relatively absent from the Finnish abortion debate. In Finland, the abortion question was more tangled up in demographic aspects.

The demographic transition developed alongside the rise of individualistic and liberal values. The first year of the study, 1955, belongs to the first demographic transition, which is considered to have started in the 1910s in Finland. Although the fertility rates witnessed a steep rise in Finland when the so-called baby-boom generations were born, Marketta Ritamies $(2006,9)$ sees the fast fertility growth as the result of postponed childbearing during the war, a temporary phase before the second demographic transition that led fertility decline to continue. The year 1968 falls under the second demographic transition with its emphasis on liberalization of values and family life. During the transitions fertility rates declined substantially in all of Europe. The decline is considered to result from rising living standards and reduced mortality, individualism, and diffusion of contraception. (Ritamies 2006, 20-21; Lesthaege 2010.) According to the demographic transition theorists, during the first transition pregnancies were prevented either in order to avoid childbearing entirely (avoiding or stopping) or to prolong the time between consecutive births (spacing). The second transition period showed more individualistic viewpoints. This time pregnancies were postponed as parents wanted to wait for a more suitable time for childbearing. (Lesthaege and Neels 2002, Bankirole, Sing and Haas 1998.)

The process of individualization can rise from rights that do not yet prevail but instead are potential that the surrounding society can encourage people to use (Cornell 1995, 5). Even if the Finnish Abortion Act of 1950 was not passed as a sign of more liberal values or of individual freedom to decide (Meskus 2003, 231-232), the social-medical indication that was included in the Act left the authorities a possibility to let women fight for their childbearing decisions. On this score, the process of individualization 
can be measured by the institutions of the Abortion Act. If potential materialized into rights, it might have not meant state-assured self-determination for all women but was, nevertheless, a significant step in the process of individualization.

\section{The creation of the 1950 Abortion Act}

The 1950 Abortion Act was the first act to legalize induced abortion in Finland. (Below, I refer to induced abortions as abortions unless otherwise specified.) Before this, the only abortion related legal provision was found in the Penal code. Before 1950 abortion was legal only in cases where the mother's or the fetus's life was in danger. The 1950 Act made abortion legal up to 16 weeks gestation if the abortion had medical, ethical or eugenic grounds that were confirmed by two certificated practitioners. Social indication itself did not justify induced abortion but was to be considered alongside with medical indication. Ethical grounds existed if the pregnancy had resulted from incest or rape or if the woman was under 16 years of age. This was the only age-related basis for abortion. The Act did not include abortion grounds based on old age. Eugenic grounds meant that the woman or the father-to-be were believed to have mental or severe physical illnesses or other faults that the offspring was feared to possess. The Act, however, did not allow abortions to be performed without the woman's consent. The requests for abortion on ethical or eugenic grounds were to be presented to the National Board of Health who had the final ruling power. (The Abortion Act 82/1950.)

The Abortion Act was the work of the legislative Committee appointed by the Finnish government in 1941 in order to solve the growing problem of illegal abortions. According to the Abortion Committee, pronatalism was a starting point for abortion policies not only in totalitarian countries but also in democratic states at the time (Com. 1945, 147). Although the health risks of illegal abortion were considered, the main concern appeared to be the menace of population decline, as fertility rates decreased notably in the beginning of the $20^{\text {th }}$ century in Europe (ibid., 148; Meskus 2001, 288).

The Abortion Committee felt it was important to understand the abortion-wishing women in order to prevent them from resorting to this "unnatural act" (Com. 1945, 1). The women were seen as helpless and unaware. The will for abortion was perceived to result from social factors, which in most cases equaled poverty. The social misery and economic distress of mothers was understood, as these women were exhausted from housekeeping and multiple previous births. In these cases, the Committee found the use of social-medical indication more understandable, as one family member more could have drastically deteriorated families' living conditions and could have worn out mothers entirely. Abortion intentions appeared to be acceptable to women who already had performed their citizen duty as a mother. The experts of the Committee argued, however, that the married women's abortion wishes tended to vary from those of the unmarried women. Financial need was also considered the source of unmarried women's abortion 
wish, since they would have been left alone to take care of their offspring. Still, according to the Committee, the social disapproval experienced by single mothers was their greatest motive for abortion (Com. 1945, 24-28). This disgrace was seen as unfounded. Single women who were earlier frowned upon if pregnant were now suitable to give birth in order to advance population growth (Nätkin 1997, 73; Helén 1997, 41).

Abortion wishes were also considered to rise from the declining of Christian moral values caused by modern lifestyle. The Committee expressed its concerns over the fact that pregnancies were not seen as inviolable states of godly order but as conditions that could be subjected to reasoning and volition. However, in the end, the Committee did not give much weight to the abortion wishes aroused by liberal thoughts. It was seen uncommon since women generally were to desire motherhood, for it was simply considered the natural course of life (Com. 1945, 34-35, 150-151).

The justification of social indication caused opposite opinions the most during the legislative process. Although social and financial distress was understood to be the leading motive behind illegal abortions, most doctors and legislators preferred preventive measures to the possibility of abortion. They insisted that the social and financial problems would be solved if the mothers would receive suitable guidance and support. The Committee advocated taking preventive measures by improving maternal care. Different policies overseas, especially German maternal care from the 1930s and 1940s as well as the national socialistic Mutter und Kind -organization were considered ideal examples. (Com. 1945, 79-89.) The Committee ended up incorporating the social indication to the medical indication, a decision quite similar to the legislation enacted in Sweden a few years earlier. Thereby, the abortion was transformed from a criminal to a medical question of which doctors were responsible. (See also Helén 1997; Meskus 2001.)

\section{Abortion prevention and social counseling services}

The abortion prevention strategy of 1950 can be seen as a continuum of a consistent line of family policies in Finland from 1930 onwards. Like any other policy, preventing abortions aimed at protecting families and achieving beneficial population growth. The year the abortion Committee was appointed, was also the year when the Family Federation of Finland was founded to advance national pronatalism. It was then believed that in order to ensure population growth, it would be ideal for each Finnish family to have at least six children (Rauttamo 1980, 64; See also Nätkin 1997, 62-63; Piensoho 2001, 86-87). The Family Federation had named the prevention of illegal abortions as its most important pronatalist mission. The federation had been very active in the legislative process and the 1950 Abortion Act came to be very close to the federation's proposal. Once the abortion prevention strategy was composed, the responsibility of the work was given, on the federation's own initiative, to its social counseling services under the supervision of the National Board of Health. 
The objective of the work was to lessen the financial and social distress experienced by mothers and to offer them guidance that would prevent any abortion intentions. The key was to find effective ways of supporting women who had received a negative abortion decision. The abortion-seeking women were expected to turn to the social counseling services, where with the help of the maternal care professionals they would see alternative solutions to their problem. Therefore, it was essential that all unwillingly pregnant women were brought to the domain of health care and personal guidance. Consequently, abortion-seeking women were helped in all other ways but admitting pregnancy termination (Helén 1997, 32, 42-47; Nätkin 1994, 143-144).

The first professional the abortion-seeking woman was to meet at the counseling service was a social nurse, often a nurse or a midwife by training. Her job was to gather information on the women and offer them support and guidance. In most cases, the social nurse showed the women to the doctor's appointment and took care of all further support and follow-up. Medical grounds for abortion were reviewed in the medical examination. If the doctor favored abortion, the case was sent to the counseling service's abortion board. The board consisted of doctors from different fields of specialty who judged each case based on the doctor's opinion and the social nurse's report.

The social counseling services were established in the turn of the 1950s as the clientele of the Family Federation's marital counseling services began increasingly to ask for advice on unintended pregnancies. The work had presumably its example in Sweden where abortion prevention had been concentrated to advice bureaus operating in the hospital premises (Lennerhed 2008, 149-153). The Finnish social counseling services were founded in Helsinki, Turku and Tampere. The new counseling services were meant to offer all pregnant women or women in need of contraceptive advice guidance on issues related to family and reproduction.

The social counseling services welcomed annually hundreds of women with unintended pregnancies during the 1950s and 1960s. Unfortunately, there is no data available from all the years of action but between the years 1965-1968, almost 8,000 women visited the social counseling services. They were mainly abortion-seekers. During these years, 28 percent of the women requesting abortion from the counseling services in Finland obtained an affirmative decision. Around one in five (17\%) of these decisions were taken at the Tampere social counseling service. During 1965-1968, the abortions admitted from the Tampere counseling service composed 12 percent of the overall number of abortions performed in the province of Häme. Considering that the counseling service had only one office in the town centre, this particular counseling service probably became familiar to many unwillingly pregnant women in the area.

Altogether one tenth of abortions performed in Finland during 1965-1968 had received permission from the Family Federation's social counseling services. Over half of these abortions were granted from the Helsinki social counseling services where the number of 
abortion-seeking women was 1.5 times greater than in Tampere and Turku combined. This regional difference was noted also by the 1968 Abortion Committee. The typical "abortion milieus", regions where abortions were more likely to be performed, were characterized as urban with higher income level and standard of education, low fertility, high divorce rates and high density of physicians. (Com. 1968, 17-18.) The Committee did not, however, take into account the abortion-seeking women. High incomes, level of knowledge and liberal ways of thinking may have affected abortion decisions in the cities. Nevertheless, there seemed to be a great amount of abortion intentions in all three regions.

\section{Results: Abortion-seeking women in the 1950s}

During 1955, the first period under review in this study, 3,659 abortions were performed in Finland. 90 abortions were perfomed to women whose place of residence was Tampere and 558 to women living in the province of Häme (NBH Statistics 1955).

In 1955, altogether 215 (97\%) of the 222 women visiting the Family Federation's Tampere social counseling service sought abortion. Thirty-four of them (16\%) got an affirmative response from the board to have an induced abortion, or induced abortion and sterilization. Seven (3\%) women visiting the service wished for advice on contraception or support on childbearing.

Most of the women seeking abortion were married with children (83\%) and every other of the women had four or more than four children. Only one tenth of the women were single, three percent divorced and three percent widowed. Nearly all the women were uneducated and of lower social class. Most of them were housewives but some women were also forced to agricultural work or factory work because of their poor financial situations. Social and financial distress was the principal reason presented when seeking abortion. The majority of the mothers seemed to live in utmost misery as they were physically and mentally exhausted from multiple births and hard domestic work. In addition, they often lacked decent living conditions.

In most cases, women managed the household and provided for their children alone even if the women were married. The men were described to have "erratic life styles". According to the women's stories, their spouses were often absent, behaved poorly, even violently and abused alcohol. Many women named the actions of the men at home as the ultimate reason for their abortion wish. Some husbands even adviced their wifes to "take care of it" as described by one mother visiting the counseling service, for it was the woman's responsibility to find a solution to the unexpected pregnancy. These women explained they had nothing against children themselves but described their current situations as "unbearable". Still they were encouraged to endure. 
Table 1. Legal abortions in Finland.

\begin{tabular}{lcc}
\hline Year & Abortions in total $(\mathbf{n})$ & Abortions per $\mathbf{0 0 0}$ live births \\
\hline $\mathbf{1 9 5 1}$ & 3007 & 32.2 \\
$\mathbf{1 9 5 2}$ & 3327 & 34.2 \\
$\mathbf{1 9 5 3}$ & 3802 & 41.8 \\
$\mathbf{1 9 5 4}$ & 3699 & 41.1 \\
$\mathbf{1 9 5 5}$ & 3659 & 40.7 \\
$\mathbf{1 9 5 6}$ & 4090 & 45.9 \\
$\mathbf{1 9 5 7}$ & 4553 & 52.3 \\
$\mathbf{1 9 5 8}$ & 5274 & 64.9 \\
$\mathbf{1 9 5 9}$ & 5773 & 69.3 \\
$\mathbf{1 9 6 0}$ & 6188 & 75.3 \\
$\mathbf{1 9 6 1}$ & 5867 & 71.6 \\
$\mathbf{1 9 6 2}$ & 6015 & 73.9 \\
$\mathbf{1 9 6 3}$ & 5616 & 68.1 \\
$\mathbf{1 9 6 4}$ & 4919 & 61.3 \\
$\mathbf{1 9 6 5}$ & 4782 & 61.5 \\
$\mathbf{1 9 6 6}$ & 5219 & 67.3 \\
$\mathbf{1 9 6 7}$ & 5618 & 72.9 \\
$\mathbf{1 9 6 8}$ & 6288 & 85.6 \\
$\mathbf{1 9 6 9}$ & 8175 & 121.5 \\
\hline $1.1 .-31.5 .1970^{*}$ & 4180 & \\
$1.6 .-31.12 .1970^{* *}$ & 10577 & \\
\hline $\mathbf{1 9 7 0}$ & 14757 & 229.5 \\
$\mathbf{1 9 7 1}$ & 20622 & 339.1 \\
$\mathbf{1 9 7 2}$ & 22146 & 413.2 \\
$\mathbf{1 9 7 3}$ & 23362 & 229.5 \\
$\mathbf{1 9 7 0}$ & 14757 & 339.1 \\
$\mathbf{1 9 7 1}$ & 20622 & 377.7 \\
$\mathbf{1 9 7 2}$ & 22146 &
\end{tabular}

* The 1950 Abortion Act in effect

** The 1970 Abortion Act in effect

Source: The National Board of Health. Statistics 1953-1975. (Yleinen terveyden- ja sairaanhoito. Oikeuslääketieteelliset toimenpiteet. Vuodet 1950-1973. Suomen virallinen tilasto. Lääkintöhallitus, Helsinki 1953-1975.)

A 35-year old mother with poor health was living in a one-room apartment with her three children and an abusive husband. She stated that she could not take on a fourth child since they were already living "a life that should not be endured by any wife or child." She even had two social service expert's opinions recommending abortion but her request was not met at the counseling service. The nursing staff belittled the behavior of the male spouse and referred to it as "marital problems" or "family difficulties", for which the woman as the family's primary emotional caretaker was responsible.

The documents often depict a pregnant woman acting without relying on or consulting her husband. With very few exeptions, the women left men out of the children-related decision-making. After multiple births and after adjusting to their family difficulties, the women reviewed their situation focusing on their own ability to cope. The data demonstrate the mothers' resilient struggle to survive the, at times difficult, every day 
life. Many large families lived poorly in cramped apartments depending solely on the mother's incomes. The women implied they could not trust their husbands to help. "He will never support his family, since he is so mean." stated one abortion-seeking mother. The abortion wish was often represented as the only means for the family that is the mother and her existing children - to survive.

Some women simply wanted to rest after frequent births. Since they could not afford or did not have access to actual contraceptive methods on a regular basis, they turned to abortion as a method of birth spacing. Some women explained that they wanted more children later on. Others wished to stop childbearing entirely. Over one third of the married women visiting the counseling service had five or more children. Some even had ten or more. These women wished to find a rescue in a situation where they felt they "were not able to take on yet another child." Many women explained they had "suffered from the incessant fear of pregnancy". One 37-year-old pregnant mother who had already given birth to eleven children and had experienced two spontanious abortions came to the counseling service since she was "feeling week and tired as well as agitated towards her children". Her exhaustion was medicalized and she was admitted abortion on the grounds of her poor health.

During 1955, only one-fourth of the women visiting the three counseling services received an affirmative abortion decision. At the Tampere counseling service half of them were women over thirty-five. Having multiple children improved chances to receive abortion. In Tampere, thirty women of the forty-four who were granted abortion had four or more than four children. In the cases of the mothers with multiple children the diagnosis was usually "asthenia universalis", general weakness. Stopping childbearing after multiple children was evidently perceived as an adequate reason to obtain termination of pregnancy by the social service professionals, for 73 percent the forty-four women who were admitted abortion had the procedure done together with sterilization. This additional procedure was not requested by the women themselves but many consented to the doctor's proposition.

The considerable number of sterilizations reveals the inadequate level of sexual knowledge. The level of knowledge was lower with the older women. Most women visiting the counseling service reported not having used birth control at all. Not only were contraceptive methods expensive and unattainable due to long distances, they were also met with suspicion - if not by women then by their partners, some of whom strongly opposed contraception, according to the women. A 23-year-old mother of two claimed her husband to have banned her from using birth control pills since he thought it could have resulted in her wife being unfaithful. 
Table 2. Requests and decisions made at the Family Federation's social counseling services in 1955 and 1965-1968.

Women seeking abortion (abortion or abortion and sterilization) (n)

\begin{tabular}{|c|c|c|c|c|c|}
\hline & 1955 & 1965 & 1966 & 1967 & 1968 \\
\hline Tampere & 215 & 242 & 302 & 362 & 377 \\
\hline Turku & 263 & 400 & 430 & 456 & 528 \\
\hline Helsinki & 514 & 1127 & 1173 & 1287 & 1221 \\
\hline Total & 992 & 1769 & 1905 & 2105 & 2126 \\
\hline \multicolumn{6}{|c|}{ Women seeking sterilization (n) } \\
\hline & 1955 & 1965 & 1966 & 1967 & 1968 \\
\hline Tampere & 1 & 33 & 36 & 70 & 64 \\
\hline Turku & $\mathrm{n} / \mathrm{a}$ & 118 & 102 & 114 & 89 \\
\hline Helsinki & $\mathrm{n} / \mathrm{a}$ & 63 & 81 & 107 & 126 \\
\hline Total & $\mathrm{n} / \mathrm{a}$ & 214 & 219 & 291 & 279 \\
\hline \multicolumn{6}{|c|}{$\begin{array}{l}\text { The share of affirmative abortion decisions } \\
\text { (abortion or abortion and sterilization) (\%) }\end{array}$} \\
\hline & 1955 & 1965 & 1966 & 1967 & 1968 \\
\hline Tampere & 15.8 & 21.0 & 24.9 & 23.2 & 41.6 \\
\hline Turku & 36.1 & 19.7 & 17.9 & 28.0 & 32.3 \\
\hline Helsinki & 25.3 & 23.9 & 23.4 & 28.1 & 37.1 \\
\hline Total & 25.7 & 22.6 & 22.3 & 27.2 & 36.7 \\
\hline
\end{tabular}

Source: Unpublished statistics from the Tampere social counseling service.

Another 28-year-old mother of four explained she had been using birth control until her drunken husband had thrown her pills into the fireplace arguing that "those pills were not needed in the household". He thought the pills "numbed" her wife but he refused to wear a condom instead. Ironically, the same men were angry to hear of their wife's pregnancy. A 21-year-old mother of one told her husband thought "she was odd" since "she went and got pregnant immediately if proper birth control methods were not used".

The most popular methods used by the women visiting the counseling service, condom and coitus interruptus, were male-dominated and left the women somewhat at the mercy of their partner's sense of responsibility. According to the data, single women partly received dissimilar treatment and were not always treated equally compared to the married and the widowed. They were less likely to receive contraceptive advice, for the Family Federation's policy was to give contraceptive advice mainly to married women (Auvinen 1991, 223). If looking at the total share of abortion admitted to the women visiting Tampere counseling service in 1955, including the abortions approved by the National Board of Health, the single women had equal probability $(20 \%)$ in obtaining abortion as the married women. However, their affirmative decisions based largely on eugenic grounds, which were rarely applied to the married or the widowed women. The single women were diagnosed as "debils", "infantile" and "idiotic". As "debils", they were to obtain abortion only together with sterilization. The use of eugenic indication bespoke of the implementation of racial hygiene that was common to all western states during the 1950s. 
In comparison to the women who obtained abortions in the whole country in 1955 and 1958, young and childless unmarried women were less often admitted abortions at the Tampere social counseling service than nationwide. Only one-fifth of the women admitted abortion had two or less than two children. In the whole country, these women made up a half of those who had the procedure performed in 1958. (NBH Statistics 1955 and1958.)

\section{Results: Abortion-seeking women in the 1960s}

6,228 legal abortions in 1968 was the highest abortion rate up to that point under the 1950 Abortion Act. 300 abortions were perfomed to women whose place of residence was at Tampere and 1,004 to women living in the province of Häme (NBH Statistics 1968). 12.4 percent of all the abortions admitted in Finland in 1968 were granted from the Family Federation's social counseling services.

Altogether 377 women seeked abortion from the Tampere social counseling service. Abortion requests came increasingly from young childless women, divorcees and mothers of one or two children, albeit married women (68\%) and mothers of multiple children still accounted for the majority of all abortion-seeking women. Compared to 1955 the share of single women and women under twenty had grown. The maturing Post-World War II baby boomer generation contributed naturally to this rise. Also, the women over thirty-five made up a greater share (37\%) than before. Women requested abortions pleading to reasons very similar to the ones in 1955, that is, to familial difficulties and to financial grounds. On the contrary to the previous year of the study, a financial situation leading to abortion intentions did not always refer to extreme financial need but to the financial inconveniences the unexpected child would entail.

Families wanted to determine themselves the number of children they were to have. The data of 1968 indicate that the ideal of two-child families, which was long popular in cities, began to gain a stronger foothold also among the lower classes. The ideal number of children had already declined to 2.9 in the 1950s (Kotimainen gallup, HS 14.1.1954. Cit. Ritamies, Riihinen, Penttinen and Pulkkinen 1984, 63). There are little signs of this decline in the 1955 data. Contraceptive behavior still appeared to be far off from determined family planning, as most couples used contraceptives irregularly and family planning continued to rely on the male-dominated methods.

The young unmarried women seeking abortion were either adolescents or women in their twenties not willing to start a family even if they were in a relationship. These women did not abstain from having children entirely but requested abortion in order to postpone first birth until their graduation or some other better time in life.

In 1968 a greater proportion of women were granted abortion after visiting the counseling service than in 1955; the share of admitted abortions and sterilizations for all women had gone up to 42 percent from that of 16 . The growing number of single women 
seeking abortions resulted in a slightly larger share of abortions granted to childless and unmarried women. Even so, married women with children as well as widowed were more likely to receive abortions than unmarried ones in 1968. 44 percent of the married women visiting the clinic were admitted abortion, as only 27 percent of the single women received an affirmative decision.

In 1968, however, there were fewer sterilizations granted together with an abortion than in 1955. Sterilization was mainly given to older women who had wished to stop childbearing and would not otherwise have been able to prevent pregnancies. Unlike in 1955, abortions together with sterilizations on eugenic grounds were rare. Instead, a growing number of women were granted abortion as a temporary solution to an unintended pregnancy.

Clearly, the indication most often used for abortion in 1968 was psychiatric grounds. This was in conformity with the abortion grounds most often used in the whole country (NBH Statistics 1968). Problematic family affairs, young age as well as the challenging economic situations were grounds that furthered obtaining abortion more in 1968 than in 1955. However, these grounds alone did not guarantee abortion. For instance, young women who had gotten pregnant through rape faced a particularly hard time fighting for their right to terminate a pregnancy. In practice, abortion was possible only if the crime had been reported and if charges had been pressed. This with all applications and doctor's appointments took time. Thereby, in the cases of these women, the National Board of Health finally stated that since the pregnancy had endured longer than 16 weeks, abortion was no more an option. Apparently, this happened to several Finnish women (Sumu 1970, 84-89).

In some cases, women's despair and depression was medicalized so that it was possible to grant abortion on medical grounds. It was not enough that the women merely wanted abortion. This is why some women were diagnosed with depression (reaction depressiva) or exhaustion (exhaustio). One young woman's hesitation on childbearing translated even to "immature emotional life". Another woman who persistently demanded her right for abortion was diagnosed with a "difficult control tendency". Also the abortion wishes of the few educated women that visited the counseling service were met, bar none. A 26-year-old pregnant woman with a master's degree was described by the nurse as "smart" and "of good family". She was very persistent and was sent to a psychiatrist. When she told him that "the child would break all living's worth", she was diagnosed with a depression and admitted abortion. The medicalization of women's thoughts was also favorable to the women themselves in situations where they could not have otherwise been able to obtain abortion.

All in all the practices of admitting abortions had changed. Some women obtained abortion, for they were familiar with the conventions of the counseling service and knew for instance how to behave in order to qualify for psychiatric grounds. Although 
women were aware of the little possibilities they had for abortion, they still came to the counseling service. The fact that the women were heard there implied that they were in a position to bargain. Women seemed overall more determined to get their way in 1968 than in 1955, which can be seen as a sign of growing individualism and life planning. The authority of the professionals was more often questioned and a negative abortion decision was rarely accepted. If abortion was not possible by the official means, the women were ready to resort to illegal abortion and were not afraid to declare it at the appointment. One women first visiting the counseling service pleeded that the "counseling service would not force one to resort to illegal and precarious methdos". Still she warned, "the pregnancy would be terminated no matter what". Another woman informed the nurse that she would "not have [the child] even if it meant going to prison".

Women's own networks provided them with information on illegal abortions, which is evident from the patient data as well as the abortion stories collected by the Sexpo Foundation (Sumu 1970; Fischer 1999; Lennerhed 2006). When learning of the negative decision some women declared they had already "booked an abortionist" since they had known that "the counseling service was going to be no good". Twenty women did not follow through with their abortion request. Some informed that they had forwent their plans to abort; others simply did never again appear to the counseling service. It is probable that some of them acted their wish to abort illegally.

Regardless, women expressed their will to have official permission, for it was both the legal as well as the safest way. One woman put it into words: "Illegal abortion will only be my last resort, since I want to be able to have children later on." Many shared this opinion (see also Sumu 1970). In spite of the blatant difference between the authority objectives and the women's personal endeavors, many of the abortionseeking women wanted to follow the rules and even returned to the counseling service after having once received a negative decision. Years later they hoped the board would be more favorable to them.

Although the board had the final power of decision, an individual doctor had a strong influence on the matter. The doctors of the Tampere social counseling service were remarkably stricter and more united in their decisions in 1955 than in 1968. The patient data of 1968 reveal that the doctors' opinions were utterly dissimilar at times. They even walked over each other's decisions. One 38-year-old pregnant mother of four was not admitted abortion when first visiting the counseling service. Although the doctor saw the women's life story "grim and tragic" he did not "detect a severe illness" and only recommended sterilization after the childbirth. When hearing of the decision, the woman's husband contacted the counseling service acting "very difficult" and demanding for the abortion approval. The couple returned to the counseling service, met with a different doctor and got an affirmative decision for abortion, which the board later approved. 
If the experts disagreed on the social indication during the legislative work of 1950 Abortion Act, the divisive social indication also turned out to be the reason why the Act required renewal in the end of the 1960s. The doctors desperately needed more guidance in applying the arguments of social grounds. Women on the other hand, were increasingly claiming for their right to decide on their body, family and life. Compared to the public debate on abortion and sexual moral that accelerated from 1965 onwards, the institutions of the social counseling services changed relatively late. As late as in 1967 only 23 percent of women obtained abortion from the Tampere counseling service. Next year the share of affirmative decisions had doubled. For one, this might be explained by the shift in the doctor generation. At the same time, women's right to abort was more widely acknowledged among experts. In the end of the 1960s, the newly appointed Abortion Committee and the international attention drawn to family planning rights may have led to the more liberal attitudes at the counseling services. The abortion prevention work, upon which the social counseling service operations were built, seemed to have run its course.

\section{Discussion and conclusions}

This is the first study of the interaction between abortion-seeking women and social counselors in Finland as reflected in official documents. I have focused on the abortionseeking practices that some Finnish women encountered during the 1950s and 1960s. Since the social counseling services' mission was to keep abortions at minimum, most of the women's abortion requests were not fulfilled. Although some of the abortion intentions were met with support and understanding from the social nurse, the abortion practices relying on the pronatalist aims collided strongly with the women's situations and expectations.

Most of the women requesting abortion were older women with multiple children and of lower social class. According to the documents, women's abortion intentions were nearly always equated with social and financial distress. Thereby the Committee's assumptions of abortion-seeking women as merely selfish and immoral were off the mark.

The women generally came to the social counseling service alone and seemed to make the decisions without their spouses. Men were often described as absent or even mistreating their families. Women's possibility to decide on their own childbearing was challenged already at home, as they did not seem to be in the position to decide on the birth control methdos used. A Finnish survey from the 1970s shows that the maledominated contraception was used more irregularly than other methods and might have thus been a considerable reason for unintended pregnancies and abortions. According to the same survey, men's level of sexual knowledge was generally higher than that of women (Sievers, Leppo and Koskelainen 1974, 426-428). 
The data demonstrate, especially on mothers of multiple children, the Finnish mother's resilient struggle and the idea of the ever-dutiful mother citizen. Women's own perseverance comes across as a survival story where they already had sacrificed enough for their families. The maternalistic emphasis is obvious. The lack of male support made it perhaps impossible to stress the meaning of the whole family. The focus of the story is not on the individual nor on the family, but on the mother and her self-evident task. If social motherhood was supposed to ensure women a way to the society (see Anttonen 1994, 220), women as resilient mothers turned out to be still tied them to their homes.

In 1955 , only 16 percent of the women got an affirmative decision from the counseling services. According to the patient data almost three-thirds of them had abortion admitted together with sterilization. Most of the women who were granted abortion were older women with multiple children. They were diagnosed as "generally weak". These grounds for abortion varied greatly from that of the younger unmarried women who were allowed abortion and sterilization as often as the married women but mainly on eugenic grounds. According to the experiences written by the women themselves in the turn of the 1970s, sterilization was at times held as a precondition to abortion regardless of the woman's age. Many of them acquiesced, youngest ones being eighteen years old (Sumu 1970, 136-138).

The key factor in obtaining abortion seemed to be the number of children the women had. Seven out of ten women with affirmative abortion decisions in 1955 had four or more than four children. If preventing the abortions of younger women with few children was the goal of the abortion prevention work, the social counseling service was more successful in this task compared to the rest of the country.

In 1968 the majority of the abortion-seekers were still married (68\%) and in most cases had more than one children (68\%). If maternalistic outlook came across from the stories of most mothers before, during the latter year of study maternalism was accompanied by individualistic characteristics. The reasons for seeking abortion were somewhat changing. The improvement of living standards, the possibility to educate oneself and the increasing demands for sexual equality among other things represented the more modern way of life that was revolutionizing women's offset to decide on their future and childbearing. A greater will to systematic family and life planning is evident according to the patient data of 1968 .

Abortion motivation presented in the social counseling service was thereby equivalent to the attitudinal changes towards childbearing presented in the demographic transition theories. Mothers of four or more than four children in 1955 and some also in 1968 wished to avoid childbearing in order to either prolong the time between births (spacing) or stop having children definitely (stopping). In 1968, on the other hand, unmarried women wanted to postpone their childbearing to a more suitable moment 
(postponing). These above-mentioned reasons were typical for preventing pregnancies during the first demographic transition starting from the beginning of the $20^{\text {th }}$ century. (See Lesthaege and Neels 2002; Bankirole, Sing and Haas 1998.)

The admitting practices loosened notably at the counseling services during the 1950 Abortion Act. In 1968, 42 percent of the women were admitted either abortion or abortion and sterilization. The use of eugenic indication dropped drastically, which can be seen as a sign of the decreasing significance of racial hygiene in pronatalist policies. Most of the women received affirmative decision on psychiatric grounds. In order to allow abortion these women's poor financial or family conditions needed to be medicalized for instance as "gravidity depression" or "exhaustion". Controversially, gaining full power of decision over one's own body required disguising one's abortion wish into a medical condition, since in the eyes of the authorities a healthy woman could never want abortion.

If obtaining abortion was more probable in 1968 than in 1955, the grounds on which abortions were granted were, however, still inconsistent, if not random. Without the women's own active efforts, the chances on obtaining abortion were slim. Active pursuing of this sexual right demanded knowledge. Therefore, women were not equal in relation to one another. Ignorance was far from bliss. The abortion-seeking women at the Tampere counseling service had perhaps even lower level of sexual knowledge, as they were mainly uneducated and of lower social class. They were not familiar with the legislation or with their right to appeal. As Sumu $(1970,83)$ has shown, women had to acquire all information on abortion seeking themselves since information was not systematically offered to them.

In the end, the improved chances in obtaining abortion resulted mainly from the changing doctoral practices. The abortion statements given from the counseling service varied greatly depending on the doctor in charge. The data demonstrate that the expert power was composed of individual actions and human discretion. If abortion prevention is regarded as an example of modern male expert power exercised on women (see Helén 1997), it can not be seen as uniform or absolute.

In addition to women being treated unequally in obtaining abortions at the counseling services, the inequality between different social classes was presumably even greater. Firstly, the data show that the lower classes had very little information and money to prevent unintended pregnancies. Secondly, the women could not afford to pay for private sector doctors who more often permitted abortions. In addition, the market of illegal abortions was quite different depending on one's social status. The more expensive abortions that the upper class women had done were considered relatively safe, as poorer women were forced to resort to less expensive and thereby dangerous terminations - or do the procedures themselves. (Sumu 1970; Lennerhed 2006, 57-59.) 
Regional equality didn't fully prevail, since registered doctors who had the power to admit abortions worked more in the urban than in the rural areas during the 1950s and 1960s (Com. 1968, 18-19).

The women visiting the social counseling service emphasized their right to decide on their own childbearing already during 1955. In 1968, they were even more determined. They expressed their will firmly, criticized the negative decisions and told the nurse openly about their intentions to turn to illegal abortion if necessary. The data support the results of previous studies that illegal abortion seemed widely accepted among the lower class women (Lennerhed 2006, 58-59; Fischer 1999). The data of this study prove that many women did not subject to the power exercised on them but knew the rules of the institutions well and tried to bend them in many ways. Women's own agency disproves the rhetoric of victimhood that was present in the Committee report and that has often been associated with the abortion question (Lennerhed 208, 60; Nätkin 1994, 152). All women were not helpless or oblivious and most importantly, they were not obedient to the society's rules. Hereby, the individual's agency also challenges the individual's unquestionable faith in authority and in collective values presented in theories of modernization (see Jallinoja 1991, 58-59; Giddens 1995). Women's opposition of collective and familistic values even questions the concept of the ever-adjusting Finnish mother citizen. If need be, women were not afraid to challenge the expert power and the ideals of the time.

Thereby, abortion prevention as a modern control system failed to restrain the individual intents of the women. Neither did the 1950 Abortion Act remove the demand for illegal abortions. The number of legal abortions increased slowly (table 1), as illegal abortions were had even more than before (Ala-Nikkola 1993, 95-97). In the 1960s, the Abortion Act was seen as a failure among many. Not only had it failed to eliminate illegal abortions but it was also criticized over the fact that it did not ensure women the power of decision that they were now seen to have (Helén 1997, 224). The second Abortion Committee report was submitted in 1968. The Act on pregnancy termination, which allowed abortion on social grounds alone, came into effect on 1st of June, 1970 (Abortion Act 239/1970). In almost twenty years abortion had developed from a criminalized act into a pronatalist matter and finally into a question of equality and self-determination.

This study supports the view that women's social class determined to which extent they could exercise their sexual rights. While some got rid of unintended pregnancy with money, others were forced to take risks or adapt to motherhood. Unequal abortion rights left the lower classes in charge of the nation's pronatalism. The patient data analyzed in this study show the reality of one population group fighting against unintended pregnancies under the 1950 Abortion Act. This unique documentation provides detailed information on the abortion seeking of the lower classes on a regional level. However, it does not tell the whole truth about seeking abortion under the 1950 Abortion Act on the country level. This remains to be studied. 


\section{References and literature}

Abortion Act 82/1950. (Laki raskauden keskeytyksestä 82/1950. Suomen asetuskokoelma 1950.)

Abortion Act 239/1970. (Laki raskauden keskeytyksestä 239/1970. Suomen asetuskokoelma 1970.)

Ala-Nikkola, Merja. 1993. Laiton lailliseksi ja kielletty sallituksi. Tutkimus raskauden keskeyttämisen laillistamisesta Suomessa. [A study on legalization of abortion in Finland.]Licenciate thesis, University of Tampere: Department of Social Politics.

Anttonen, Anneli. 1994. Hyvinvointivaltion naisystävälliset kasvot. [The friendly face of the welfare state.] In: Naisten hyvinvointivaltio, edited by Anneli Anttonen, Lea Henriksson and Ritva Nätkin. [Women's welfare state.] Jyväskylä: Gummerus.

Auvinen, Riitta. 1991. Äitiyssuojelusta perhekasvatukseen. [From maternal protection to family education.] In: Taskinen, Ritva (eds.). Perheen puolesta: Väestöliitto 1941-1991, 205-242. Helsinki: Otava, Väestöliitto.

Bankole, Akinrinola, Susheela Singh, and Taylor Haas. 1998. Reasons Why Women Have Induced Abortions: Evidence from 27 Countries. International Family Planning Perspectives 24 (3): 117-128.

Bauman, Zygmunt. 1996. Postmodernin lumo. [The spell of postmodern.] Tampere: Vastapaino.

Committee Report 1945:6. (Komiteanmietintö Mon. 1945:6. Aborttikomitean mietintö.)

Committee Report 1968: A11. (Komiteanmietintö 1968:A11. Aborttilakikomitean mietintö.)

Cornell, Drucilla. 1995. The Imaginary Domain. Abortion, Pornography \& Sexual Harassment. New York \& London: Routledge.

Ervasti, Kaijus. 1994. Lapsenmurhat Suomessa. Oikeushistoriallinen tutkimus lapsenmurharikoksista Suomessa erityisesti autonomian aikana. [Child murders in Finland. A legal historical study on child murders in Finland especially during the autonomy.] Licenciate thesis, University of Helsinki: Legal History.

Fisher, Kate. 1999. "Didn't stop to think, I just didn't want another one": the Culture of Abortion in Interwar South. In: Sexual Cultures in Europe: Themes in sexuality. edited by Franz Eder, Gert Hekma and Lesley A. Hall. Manchester: Manchester University Press.

Frank, David John, Bayliss J. Camp and Steven A. Boutcher. 2010. Worldwide Trends in the Criminal Regulation of Sex 1945-2005. American Sociological Review 75 (6): 867-893. American Sosiological Association.

Giddens, Anthony. 1994. Living in a post-traditional society. In: Reflexive Modernization. Politics, Tradition and Aesthetics in the Modern Social Order, edited by Ulrich Beck, Anthony Giddens and Scott Lash. Standford University Press.

Helén, Ilpo. 1997. Äidin elämän politiikka: naissukupuolisuus, valta ja itsesuhde Suomessa 1880-luvulta 1960-luvulle. [Politics of mother's life: female gender, power, and self-relation in Finland from the 1880s to the 1960s.] Helsinki: Gaudeamus.

Herzog, Dagmar. 2011. Sexuality in Europe. A Twentieth-Century History. New York: Cambridge University Press. 
Jallinoja, Riitta. 1991. Moderni elämä. Ajankuva ja käytäntö. [Modern life. Portrayl of the times and practice.] Helsinki: SKS.

Karisto, Antti. 1998. Pirstoutuvan elämän politiikka. [Fracturing life politics.] In: Elämänpolitiikka, edited by J.P. Roos and Tommi Hoikkala. 2000-luvun kirjasto. Helsinki: Gaudeamus.

Keski-Petäjä, Miina. 2012. Aborttitoiveet ja abortintorjunta. Raskauden keskeytyksen hakeminen 1950- ja 1960-lukujen Suomesssa. [Abortion wishes and abortion prevention - Seeking legal termination of pregnancy during the 1950s and 1960s in Finland.] Väestöliiton Väestöntutkimuslaitoksen katsauksia E 45.

Kotimainen gallup. Ihanteellinen lapsiluku perheessä. [Finnish gallup. Ideal number of children.] Helsingin Sanomat 14.1.1954.

Lennerhed, Lena. 2008. Historier om ett brott: Illegala aborter i Sverige på 1900-talet. [Illegal abortions in Sweden during the 20th century.] Falun: Atlas.

Lesthaeghe, Ron. 2010. The Unfolding Story of the Second Demographic Transition. Population and Development Review 36 (2): 211-251.

Lesthaeghe, Ron and K. Neels. 2002. From the First to the Second Demographic Transition: an Interpretation of the Spatial Continuity of Demographic Innovation in France, Belgium and Switzerland. European Journal of Population 18(4): 325-360.

Meskus, Mianna. 2001. Sikiön lähdettämisen alakulttuuri 1900-luvun Suomessa. [The subculture of illegal abortions in the 20th century Finland.] Sosiologia 4/2001.

Meskus, Mianna. 2003. Väestön elinvoima ja tahallinen keskenmeno. Raskauden keskeyttämisen politisoituminen 1900-luvun alun Suomessa. [Population vitality and induced miscarriage. Politicization of abortion in the early 20th century Finland.] In: Kansalaisuus ja kansanterveys, edited by Ilpo Helén and Mikko Jauho. Helsinki: Gaudeamus.

The National Board of Health. Statistics 1953-1975. (Yleinen terveyden- ja sairaanhoito. Oikeuslääketieteelliset toimenpiteet. Vuodet 1950-1973. Suomen virallinen tilasto. Lääkintöhallitus, Helsinki 1953-1975.)

Nätkin, Ritva. 1997. Kamppailu suomalaisesta äitiydestä. Maternalismi, väestöpolitiikka ja naisten kertomukset. [A struggle on Finnish motherhood. Maternalism, population politics and women's stories.] Tampere: Tammer-Paino Oy.

Nätkin, Ritva. 1994. Väestöpolitiikka, abortti ja äitiys: hyvinvointivaltion ammattilaisten ja naisten suhteen tarkastelua. [Population policy, abortion, and motherhood: reviewing the relationship between the professionals of the welfare state and women.] In: Naisten hyvinvointivaltio, edited by Anneli Anttonen, Lea Henriksson and Ritva Nätkin. Jyväskylä: Gummerus.

Piensoho, Tuula. 2001. Äitiyden alkumetrit. Naisten raskaudelle ja synnytykselle antamat merkitykset ja oppimiskokemukset. Helsingin yliopiston kasvatustieteenlaitoksen tutkimuksia 176. Helsinki.

Reagan, Leslie J. 1997. When Abortion Was a Crime. Women, Medicine, and Law in the United States, 1867-1973. Los Angeles: University of California Press.

Ritamies, Marketta. 2006. Sinappikylvystä ehkäisypilleriin. Suomalaisen perhesuunnittelun historia. [From mustard bath to contraception pill: the history of Finnish family 
planning.] Helsinki: Väestöntutkimuslaitoksen julkaisusarja D 44.

Ritamies, Marketta, Olavi Riihinen, Heli Penttinen, and Aimo Pulkkinen. 1984. Lapsilukuihanne - toive vai tavoite. [The ideal number of children - a wish or an aim.] Helsinki: Väestöntutkimuslaitoksen julkaisusarja D, Nro 13.

Satka, Mirja. 1994. Sota-ajan naiskansalaisen ihanteet naisjärjestöjen arjessa. [The ideals of a wartime citizen in women organizations.] In: Anneli Anttonen, Lea Henriksson and Ritva Nätkin (eds.): Naisten hyvinvointivaltio. Jyväskylä: Gummerus.

Saloheimo, Aksel. 1950. "Graviditeettidepressio" ja sen hoito. [Gravidity depression and its treatment.] Avioliitto ja lääkäri 3/1950.

Sumu, Ritva-Liisa (Ed.). 1970. Abortti. 250 suomalaisnaisen kokemukset vastentahtoisista raskauksista, abortista ja sterilisaatiosta. [Abortion. 250 Finnish women's experiences on unintended pregnancies, abortions and sterilizations.] Helsinki: Huutomerkkisarja, Tammi.

Sievers, Kai, Osmo Koskelainen and Kimmo Leppo. 1974. Suomalaisten sukupuolielämä. [Finnish sex life.] Porvoo: WSOY.

Tuomaala, Salome. 2011. Keskeytyksiä elämässä. Naisten toimijuudet aborttikertomuksissa. [Interruptions in life. Women's agency in abortion stories.] University of Helsinki: Doctoral thesis, Department of comparative religion.

Tuomainen, Raimo, Markku Myllykangas, Jyrki Elo and Olli-Pekka Ryynänen. 1991. Medikalisaatio. Aikamme sairaus. [Medicalization. The illness of our time.] Tampere: Vastapaino.

Tuomi, Jouni and Anneli Sarajärvi. 2009. Laadullinen tutkimus ja sisällön analyysi. [Qualitative research and content analysis.]Helsinki: Tammi.

Zola, Irwin. 1972. Medicine as an institution of social control. Sociological Review 4: 487-504. 